\title{
ENHANCED IN VITRO PROPAGATION OF MUSA ACCUMINATA INDUCED BY HUMIC ACID FROM COAL EXTRACT AS COMPARED WITH COMMERCIALLY AVAILABLE HUMIC ACID PRODUCTS
}

\author{
S. Dhanapal ${ }^{1}$, D. Sathish Sekar ${ }^{2}$ \\ ${ }^{1}$ Research Scholar, Department of Biotechnology, St. Peter's Institute of Higher Education and Research, St. Peter's \\ University, Avadi, Chennai, TN, India \\ ${ }^{2}$ Assistant Professor and Head, Department of Biotechnology, Arignar Anna College (Arts and Science), Krishnagiri,
} TN, India

\begin{abstract}
Humic acids (also known as the black gold of agriculture) are complex molecules that exist naturally in humic matter found in soils and are an excellent natural and organic way to provide soil with a concentrated dose of essential nutrients, vitamins and trace elements. A source of humic acids is found in soft brown coal referred to as Leonardite. The Humic acid was extracted from Leonardite collected from Neyveli and it was estimated. The estimated Humic acid was used for the micropropagation of Grand Naine (Musa accuminata) at five different concentrations $(0.1-0.5 \%)$ and compared with commercially available Keradix and Humic Rooting. The various trials were used to check the growth propagation of the Humic acid in full MS media, 3/4 MS media, 1/2 MS media and $1 / 4$ MS media and comparison was made among the samples in full MS. After the micropropagation, the explants were selected for the initiation stage and the proliferation stage. The Rooting and Shooting stage were developed in the media with the Humic acid of all the samples against the control of various concentrations and the characteristics such as the Length, height, weight of the roots and shoots were studied and the best concentration for the growth of plants using Humic acid and the media were reported.
\end{abstract}

Keywords: Grand Naine, Musa accuminata, MS media, Leonardite, Humic Rooting, Keradix, Micropropagation

\section{INTRODUCTION}

Humic substances are formed by the microbial degradation of dead plant matter, such as lignin. They are resistant to further biodegradation. Humic substances in soils and sediments can be divided into three main fractions: Humic acids, folic acids, and humin. The humic and fulvic acids are extracted as a colloidal sol from soil and other solid phase sources into a strongly basic aqueous solution of sodium hydroxide or potassium hydroxide [5]. Humic acids are precipitated from this solution by adjusting the $\mathrm{pH}$ to 1 with hydrochloric acid, leaving the fulvic acids in solution. This is the operational distinction between humic and fulvic acids. Humin is insoluble in dilute alkali. The alcohol-soluble portion of the humic fraction is, in general, named ulmic acid. So-called "gray humic acids" (GHA) are soluble in low-ionic-strength alkaline media; "brown humic acids" (BHA) are soluble in alkaline conditions independent of ionic strength; and fulvic acids (FA) are soluble independent of $\mathrm{pH}$ and ionic strength [14].

The functional groups that contribute most to surface charge and reactivity of humic substances are phenolic and carboxylic groups. Humic acids behave as mixtures of dibasic acids, with a $\mathrm{pK}$ value around 4 for protonation of carboxyl groups and around 8 for protonation of phenolate groups. There is considerable overall similarity among individual humic acids. For this reason, measured $\mathrm{pK}$ values for a given sample are average values relating to the constituent species [8]. The other important characteristic is charge density. The molecules may form a super molecule.

Secular structure held together by non-covalent forces, such as Van der Waals force, $\pi-\pi$, and $\mathrm{CH}-\pi$ bonds. Many Humic acids have two or more of these groups arranged so as to enable the formation of chelate complexes. The formation of (chelate) complexes is an important aspect of the biological role of humic acids in regulating bioavailability of metal ions [19].

Humic acid has direct effect on plant cell membrane which increases the permeability and make the mineral element move back \& forth through the membrane, resulting in an increased transport of various mineral nutrient to site of metabolic need. When humic acid is applied to plant leaves, the chlorophyll content of leaves increases. Humic substances regulate plant growth hormones and inhibit the enzyme IAA oxidase there by hindering IAA destruction. They also provide many free radicals to plant cells that assist in exerting positive effect on seed germination, root initiation $\&$ plant growth. The best source of humic substances for fertilizer use is from linarite which is highly oxidized low grade lignite containing a relatively high concentration of smaller molecular units [15]. 
Increased $\mathrm{N}$ uptake by rough fescue (Fistula scabrella Torr.) in response to application of humic substances extracted from 3 soils, while $\mathrm{P}, \mathrm{K}, \mathrm{Ca}, \mathrm{Mg}$ and $\mathrm{Na}$ uptake was unaffected [6]. Humic acid have long recognized that play a major role in producing morphological and physiological effects in plants [12] and [7]. It has been reported that humic acids are able to stimulate or inhibit plant growth depending on their differences in origin, nature and concentration. The application of humic substances to nutrient solution, to soil or sand has been documented and the results showed that they enhanced significant growth responses [20].

Tissue culture refers to the use of small pieces of plant tissue (explants) that are cultured in a nutrient medium under sterile conditions. By using the appropriate growing conditions for each explant type, plants can be induced rapidly in order to produce new shoots and by adding suitable hormones, new roots are induced. These plants can be divided usually at the shoot stage, to produce high numbers of new plantlets [16]. The new plants can be placed in soil and grown naturally. Also, healthy plants can be grown in the laboratory at any time. In vitro culture techniques of banana plants can produce thousands of plants in a relatively shorter time either using somatic embryo or apex explants which require different culture media for shoot multiplication and root differentiation [4]. Foliar sprays of HA promoted growth in many plants such as tomato, cotton and grape [1]. The present study is to study the effect of various concentrations of Humic acid in Musa Acuminata, a Cavendish variety often called as G-9 (Grand Naine) with different strengths of the Murashige and Skoog medium [11].

\section{MATERIALS AND METHODS}

\subsection{Sample Collection}

The coal sample (leonardite) was collected from Mines II of Neyveli lignite corporation, Neyveli. The commercially available Humic acid called Keradix was purchased from Akshaya Agro shop, Hosur and the Humic Rooting was collected from Genewin Biotech, Hosur.

\subsection{Extraction of Humic Acid with Various Solvents}

Humic acids were extracted from the resulting leonardite, using extraction methods that are capable of extracting humic acids $5 \mathrm{~g}$ of leonardite was extracted with $50 \mathrm{ml}$ of each of the following $(0.1 \mathrm{M} \mathrm{NaOH}, 0.1 \mathrm{M} \mathrm{KOH}, 0.1 \mathrm{M}$ $\mathrm{Na}_{4} \mathrm{P}_{2} \mathrm{O}_{7}, 0.25 \mathrm{M} \mathrm{NaOH}, 0.25 \mathrm{M} \mathrm{KOH}, 0.25 \mathrm{M} \mathrm{Na}_{4} \mathrm{P}_{2} \mathrm{O}_{7}$ ) and stirred for $1 \mathrm{~min}$. The $\mathrm{pH}$ of the suspension was maintained at 13 by addition of $\mathrm{NaOH}(20 \%$, w/v) and left undisturbed for three hours. The precipitate formation was eliminated by centrifuging the mixture at $3500 \mathrm{rpm}$ for 15 min. The supernatant was acidified with $50 \mathrm{ml}$ of $0.1 \mathrm{M} \mathrm{HCl}$ and stirred for $1 \mathrm{~min}$. The $\mathrm{pH}$ of the suspension was adjusted to 1 by the addition of $\mathrm{HCl}(10 \%$, w/v), and it was allowed to stand overnight. Both the aqueous fulvic acids and precipitated humic acids fraction were obtained by centrifuging at $3500 \mathrm{rpm}$ for $15 \mathrm{~min}$. The humic samples were dried at $60^{\circ} \mathrm{C}$ and the highest yield from each solvent extract was weighed [3].

\subsection{KOH as Solvent:}

10 gms of leonardite (Coal extracted Humic acid CHA) sample was weighed and ground. Fine particles were obtained by passing through a mesh sieve. Then the CHA sample was treated with $100 \mathrm{ml} 0.1 \mathrm{M} \mathrm{KOH}$ and mixed thoroughly, the complete dissolving of the Leonardite in $\mathrm{KOH}$ was ensured. Coal residue was then again treated with $5 \mathrm{ml}$ of $\mathrm{KOH}$. Water soluble salt of humic acid formed was filtered through a Whatmann No.42 filter paper to separate it from insolubles. $1 \mathrm{ml}$ of concentrated hydrochloric acid was added to bring the $\mathrm{pH}<2$. The humic acid was precipitated in the bottom of the beaker. The precipitate thus obtained is Potassium Humate.

All the samples namely coal (Leonardite), Keradix and Humic Rooting were estimated for the Humic acid.

\subsection{Estimation of \% Humic Acid}

The estimation of the percentage of Humic acid was elaborated by [18].

$0.1 \mathrm{~g}$ of humic acid sample was weighed, ground into a fine powder and sieved with $0.2-0.3 \mathrm{~mm}$ size mesh and dissolved in $10 \mathrm{ml}$ of extraction buffer containing $0.2 \mathrm{M}$ $\mathrm{NaOH}, 0.0032 \mathrm{M}$ DTPA (Diethylene triamine pentaacetic acid, ROLEX-Mumbai), $2 \%$ ethanol. The prepared aliquot of the sample was centrifuged to remove any particulates. The supernatant was used as the sample. $1 \mathrm{ml}$ of the sample was taken and mixed with $5 \mathrm{ml}$ of water. The Absorbance was taken at $450 \mathrm{~nm}$ using Titan Biotech Humic acid as standard (50-300mg) [2].

\subsection{Micropropagation of Grand Naine (Musa}

\section{Accuminata)}

MS Medium with full concentration, $3 / 4$ MS, $1 / 2$ MS and $1 / 4$ MS were prepared with the following concentrations of hormones and humic acid. MS medium composition for one litre for all three stages are given in Table 3. Gelrite is used instead of agar in the concentration of $2.5 \mathrm{~g} \mathrm{~L}^{-1}$ for good transparency

\section{Explant Initiation Medium}

The trials were carried out for the explant initiation medium against the control with full MS, $3 / 4 \mathrm{M}, 1 / 2 \mathrm{MS}, 1 / 4 \mathrm{MS}$. The $\mathrm{pH}$ maintained for the media was about 5.5-5.8 which was adjusted using suitable buffers.

Trial 1- Control-MS+3\% Sucrose+IAA-3mg/l+NAA$1 \mathrm{mg} / 1+$ Gelrite $-2.5 \mathrm{gm} / 1 \mathrm{In}$ the $1.1-1.5$ trials, the MS media with various concentrations of $0.1-0.5 \%$ were used.

Trial 2- Control- $3 / 4 \quad \mathrm{MS}+3 \%$ Sucrose+IAA-3mg/l+NAA$1 \mathrm{mg} / \mathrm{l}+$ Gelrite $-2.5 \mathrm{gm} / 1$. In the $2.1-2.5$ trials, the $3 / 4 \mathrm{MS}$ media with various concentrations of $0.1-0.5 \%$ were used.

Trial 3- Control- 1/2 MS+3\%Sucrose+IAA-3mg/l+NAA$1 \mathrm{mg} / \mathrm{l}+$ Gelrite- $2.5 \mathrm{gm} / \mathrm{l}$. In the 3.1-3.5 trials, the $1 / 2 \mathrm{MS}$ media with various concentrations of $0.1-0.5 \%$ were used.

Trial 4- Control- $1 / 4$ MS+3\% Sucrose+IAA-3mg/l+NAA$1 \mathrm{mg} / \mathrm{l}+$ Gelrite-2.5gm/l. Trial $4.1-4.5$ - In these trials, the $1 / 4$ 
MS media with various concentrations of $0.1-0.5 \%$ were used.

Proliferation Medium: $\mathrm{pH}$ 5.5-5.8 was found as the optimum $\mathrm{pH}$ for the proliferation media which was adjusted using suitable buffers. The growth regulators were added in the proliferation medium.

Trial 5- Control-MS+3\%Sucrose+6BAP-4.2mg/l+NAA$1 \mathrm{mg} / 1+$ Gelrite- $2.5 \mathrm{gm} / \mathrm{l}$. In the 5.1-5.5 trials, the MS media with various concentrations of $0.1-0.5 \%$ were used.

Trial 6- Control- $3 / 4 \mathrm{MS}+3 \%$ Sucrose+6BAP-4.2mg/l+NAA$1 \mathrm{mg} / 1+$ Gelrite- $2.5 \mathrm{gm} / \mathrm{l}$. In the $6.1-6.5$ trials, $3 / 4$ the MS media with various concentrations of $0.1-0.5 \%$ were used.

Trial 7- Control- $1 / 2 \mathrm{MS}+3 \%$ Sucrose+6BAP-4.2mg/l+NAA$1 \mathrm{mg} / 1+$ Gelrite-2.5gm/1. In the 7.1-7.5 trials, $1 / 2 \mathrm{MS}$ media with various concentrations of $0.1-0.5 \%$ were used.

Trial 8- Control- $1 / 4 \mathrm{MS}+3 \%$ Sucrose+6BAP-4.2mg/l+NAA$1 \mathrm{mg} / \mathrm{l}+$ Gelrite-2.5gm/1. In the $8.1-8.5$ trials, $1 / 4 \mathrm{MS}$ media with various concentrations of $0.1-0.5 \%$ were used.

\subsection{Shooting Medium}

For the shooting medium, the optimum $\mathrm{pH}$ was 5.5-5.8 which was adjusted using suitable buffers.

Trial 9- Control-MS+3\% Sucrose+Kinetin-10mg/l+NAA$1 \mathrm{mg} / 1+$ Gelrite- $2.5 \mathrm{gm} / 1$. In the 9.1-9.5 trials, the MS media with various concentrations of $0.1-0.5 \%$ were used.

Trial 10- Control- $3 / 4 \quad \mathrm{MS}+3 \%$ Sucrose+ Kinetin-10mg/l +NAA-1 mg/l+Gelrite-2.5gm/l. In the 10.1-10.5 trials, 3/4 MS media with various concentrations of $0.1-0.5 \%$ were used. Trial 11- Control- 1/2 MS+3\%Sucrose+ Kinetin-10mg/l +NAA-1 mg/l+Gelrite-2.5gm/l. In the 11.1-11.5 trials, the $1 / 2$ MS media with various concentrations of $0.1-0.5 \%$ were used.

Trial 12- Control- $1 / 4 \quad$ MS+3\%Sucrose+ Kinetin-10mg/l +NAA-1mg/l+Gelrite-2.5gm/l. In the $12.1-12.5$ trials, $1 / 4$ MS media with various concentrations of $0.1-0.5 \%$

\subsection{Rooting Medium}

For the shooting medium, the optimum $\mathrm{pH}$ was 5.5-5.8 which was adjusted using suitable buffers

Trial 13- Control-MS+3\%Sucrose+ Adenine sulphate$40 \mathrm{mg} / \mathrm{l}+$ Kinetin- $1 \mathrm{mg} / \mathrm{l}+$ Gelrite-2.5gm/l. In the 13.1-13.5 trials, the MS media with various concentrations of 0.1 $0.5 \%$ were used.

Trial 14- Control- $3 / 4 \mathrm{MS}+3 \%$ Sucrose+ Adenine sulphate$40 \mathrm{mg} / 1+$ Kinetin- $1 \mathrm{mg} / \mathrm{l}+$ Gelrite-2.5gm/l. In the 14.1-14.5 trials, the $3 / 4$ MS media with various concentrations of 0.1 $0.5 \%$ were used.

Trial 15- Control- 1/2 MS+3\%Sucrose+ Adenine sulphate$40 \mathrm{mg} / \mathrm{l}+$ Kinetin- $1 \mathrm{mg} / \mathrm{l}+$ Gelrite-2.5gm/1. In the $15.1-15.5$ trials, the $1 / 2$ MS media with various concentrations of $0.1-$ $0.5 \%$ were used.

Trial 16- Control- $1 / 4 \mathrm{MS}+3 \%$ Sucrose+ Adenine sulphate$40 \mathrm{mg} / 1+$ Kinetin- $1 \mathrm{mg} / 1$ +Gelrite-2.5gm/l. In the 16.1-16.5 trials, the $1 / 4 \mathrm{MS}$ media with various concentrations of $0.1-$ $0.5 \%$ were used.

Medium for all the above trials were prepared and poured in sterilized Tissue culture bottles to a volume of $50 \mathrm{ml}$ per culture bottle approximately, labeled and sterilized in the vertical autoclaves at $121^{\circ} \mathrm{C}$ at 15 PSI for $15-18$ minutes in autoclave. The sterilized bottles were kept under observation for one week to check for the growth of contaminants.

\section{Comparison of the Samples}

The samples namely Coal (Leonardite) (CHA), Keradix (KHA), Humic Rooting (BHA) of various concentrations 0.1 $-0.5 \%$ were used for the Initiation, Rooting and shooting stages of Musa accuminata using full MS as the medium to compare the growth of the roots, shoots and the root's height and compared against the control.

\subsection{Proliferation Stage}

Trimming of the Explant buds were done at the top and the base was dissected exactly into two halves for all the samples namely CHA, BHA, KHA and compared with the control. They were then placed in the Proliferation medium and Trial bottles were labeled as GW04-NA-P, 0.1, 0.2, 0.3, 0.4 and 0.5 respectively and taken to incubation room [17].

\section{Culture Conditions:}

Humidity: 40-45\%

Light: $16\left[\mathrm{~h} \mathrm{~d}^{-1}\right]$

Temperature: $25 \pm 2^{\circ} \mathrm{C}$.

Particulate count: class 1, 00,000 maintained by air handling unit (AHU).

Labeling of culture trays was done with operator code GW04 (MSP), date of inoculation, 51/3/11 code stage- MULTI and kept for observations.

\subsection{Shooting Stage}

At the Shooting stage, the multiplied shoots were trimmed at the top and the base was dissected into small cultures containing 2-4 multi shoots in it for all the samples namely BHA, CHA, KHA and compared against the control. The Trial bottles were labeled as GW04-NA-S, 0.1, 0.2, 0.3, 0.4 and 0.5 respectively and taken to incubation room [10].

\section{Culture conditions:}

Humidity: $35-40 \%$

Light: $16\left[\mathrm{~h} \mathrm{~d}^{-1}\right]$

Temperature: $27 \pm 2^{\circ} \mathrm{C}$.

Particulate count: class 1, 00,000 maintained by air handling unit (AHU). Labeling of culture trays with operator code GW04 (MSP), date of inoculation, 1/6/12 (week/working day in the week/year) code stage- INITIATION were done and kept for inference. After 15 days of incubation, the observations were noted.

\subsection{Rooting Stage}

At this stage, the Shooting stage cultures were dissected with the base and individual shoot bearing culture bases were 
placed in rooting medium bottles for all the samples namely BHA, CHA, KHA and compared against the control. Trial bottles are labeled as GW04-NA-R, 0.1, 0.2, 0.3, 0.4 and 0.5 respectively and taken to incubation room [9].

\section{Culture Conditions:}

Humidity: $35-55 \%$

Light: $16\left[\mathrm{~h} \mathrm{~d}^{-1}\right]$

Temperature: $30 \pm 2^{\circ} \mathrm{C}$.

Particulate count: class 1, 00,000 maintained by air handling unit (AHU).

Labeling of the culture trays with operator code GW04 (MSP), date of inoculation-3/6/12 (week/working day in the week/year) code stages- INITIATION were done and kept for inference. After 15 days of incubation, the observations were noted.

\section{Statistical Analysis}

10 replicates were carried out for each treatment. After the 21 days of in vitro propagation, plant height, mass, number of roots, root length etc. Mean, SD and variance of the above trials were analyzed for the samples HA, CHA, KHA. The data were analyzed statistically by using analysis of variance (ANOVA) and Least Significant Difference (LSD) [13].

\section{RESULTS}

\section{Quantification of Humic Acid}

The extraction of humic acids from leonardite $5 \mathrm{~g}$ with $0.1 \mathrm{M}$ $\mathrm{KOH}$ yielded $0.8813 \mathrm{~g}, 0.25 \mathrm{M} \mathrm{K0H}$ yielded $0.3312 \mathrm{~g}, 0.1 \mathrm{M}$ $\mathrm{NaOH}$ yielded $0.2216 \mathrm{~g}$ and $0.25 \mathrm{M}$ of $\mathrm{NaOH}$ yielded 0.2566 g, $0.1 \mathrm{M} \mathrm{Na}_{4} \mathrm{P}_{2} \mathrm{O}_{7}$ yielded $0.6273 \mathrm{~g}$ and $0.25 \mathrm{M} \mathrm{Na}_{4} \mathrm{P}_{2} \mathrm{O}_{7}$ yielded $0.6994 \mathrm{~g}$. Results of extractant that used for extracting humic acids from leornardite showed that the greatest yield of humic aicds was obtained in $0.1 \mathrm{M} \mathrm{KOH}$ and the lowest yield in $0.1 \mathrm{M} \mathrm{NaOH}$. So $\mathrm{KOH}$ is selected as the extracting solvent for the humic acid extraction process.
Table -1: Estimation of Extracted Humic Acid

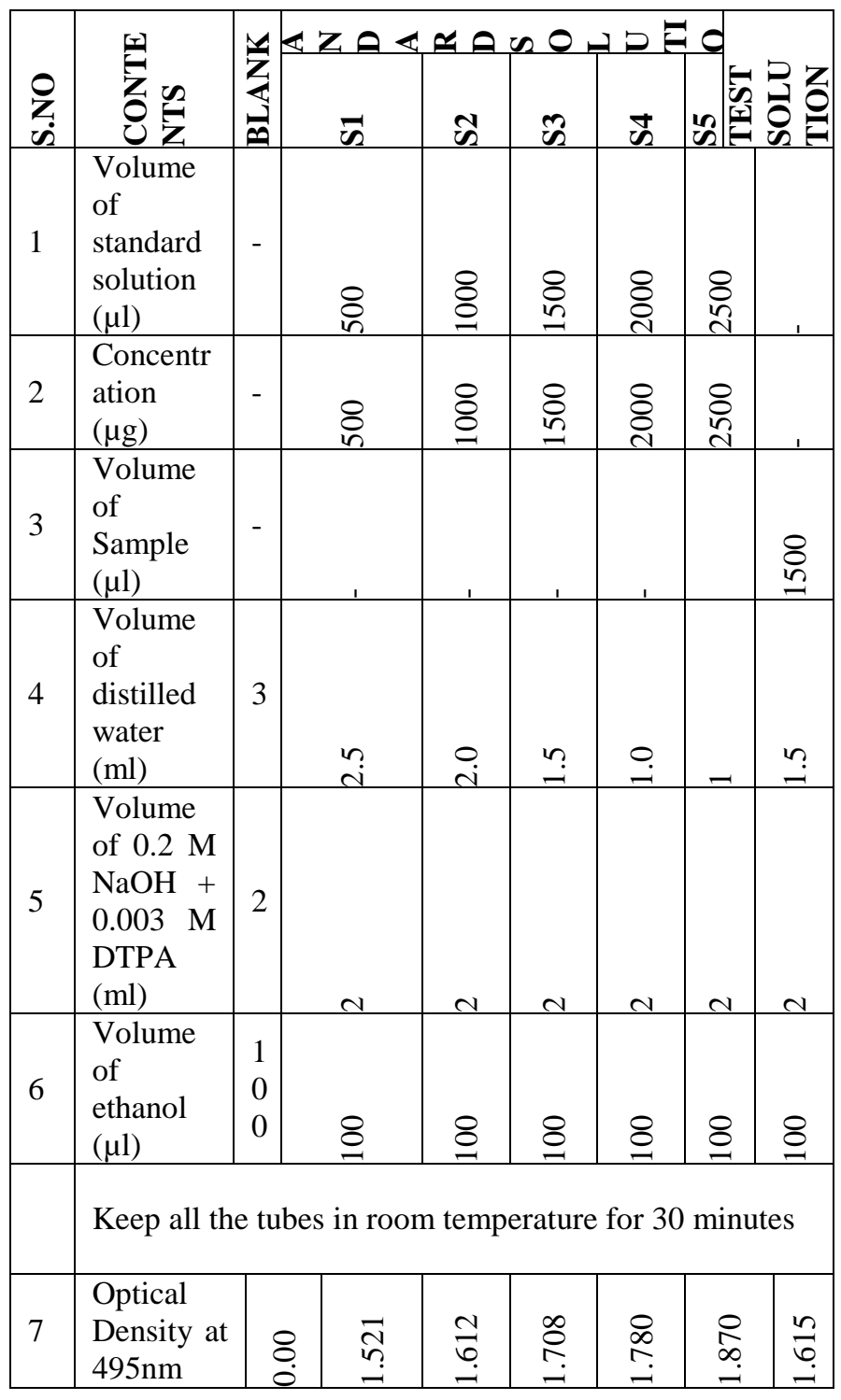

\section{CALCULATION:}

OD 1.615 corresponds to $1150 \mathrm{mg}$ of humic acid

$1.5 \mathrm{ml}$ of sample contains $=1150 \mu \mathrm{g}$ of humic acid

$1 \mathrm{ml}$ of sample contain 1000

= ---------------- X 1150

1500

$=0.666 \times 1150$

$=766.66 \mu \mathrm{g} / 1000 \mu \mathrm{l}$

$=76.6 \%$ of humic acid

$76.6 \%$ of Humic acid was derived from $10 \mathrm{gm}$ of Leonardite from mines II of Neyveli yielded by dissolving the coal (Leonarddite) with $100 \mathrm{ml}$ of $4 \% \mathrm{KOH}$. The standard Humic acid was tested against the sample. The concentration was reduced to $0.1 \%$ to $0.5 \%$ in the MS medium preparations 
Table - 2: Comparison Of Samples For The Estimation Of Humic Acid

Final Ppm For Standards

\begin{tabular}{|c|c|c|c|c|c|}
\hline $\begin{array}{l}\text { STANDARDS } \\
(\mathrm{mg})\end{array}$ & 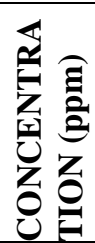 & $\begin{array}{l}0 \\
z \\
0 \\
0 \\
0 \\
0 \\
0 \\
0\end{array}$ & 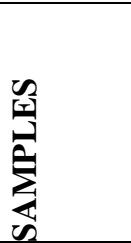 & 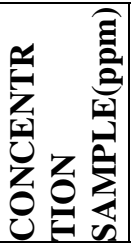 & 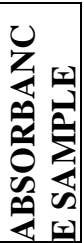 \\
\hline 50 & 50 & 0.8135 & 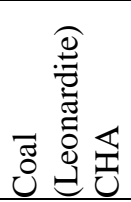 & 离 & ֻै \\
\hline 100 & 100 & 13645 & 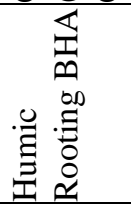 & $\frac{N}{\text { Nn}}$ & $\begin{array}{l}3 \\
b \\
\stackrel{0}{n} \\
m\end{array}$ \\
\hline 150 & 150 & 2.3203 & 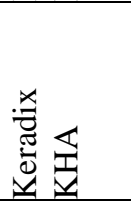 & 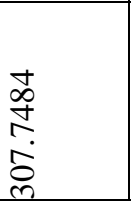 & $\begin{array}{l}8 \\
8 \\
\varnothing \\
\dot{\forall}\end{array}$ \\
\hline 200 & 200 & 2.9488 & & & \\
\hline 250 & 250 & 3.2968 & & & \\
\hline 300 & 300 & 3.7192 & & & \\
\hline
\end{tabular}

Since the samples were of $70 \%$, the standards concentration must be converted to $70 \%$ from $100 \%$. The standard concentrations for $100 \%$ were $50,100,150,200,250,300$ mg respectively. For $70 \%$, the standard concentrations were converted as $35,70,105,140,175,210 \mathrm{mg}$ respectively. The dilution factor for the estimation of Humic acid was $6 \mathrm{X}$. For $1 \mathrm{ml}$ of the sample, they were diluted 5 times as the sample concentration was high. So, the Dilution factor was $6 \mathrm{X}(1 \mathrm{X}$ $+5 \mathrm{X})$. The concentration of the samples with dilution factor was mentioned in the above table.
Table 3: Effect Of HA in the Shooting Medium

\begin{tabular}{|l|l|l|l|}
\hline COMPOSITION & $\begin{array}{l}\text { MEAN } \\
\text { SHOOT } \\
\text { LENGTH } \\
\text { IN } \\
\text { CHA(cm) }\end{array}$ & $\begin{array}{l}\text { MEAN } \\
\text { SHOOT } \\
\text { LENGTH } \\
\text { IN BHA } \\
\text { SAMPLE } \\
\text { (cm) }\end{array}$ & $\begin{array}{l}\text { MEAN } \\
\text { SHOOT } \\
\text { LENGTH } \\
\text { IN } \\
\text { KHA(cm) }\end{array}$ \\
\hline MS-control & $3.56 \pm 1.05$ & $3.56 \pm 1.05$ & $3.56 \pm 1.05$ \\
\hline MS+0.1\%HA & $4.22 \pm 1.17$ & $3.73 \pm 0.98$ & $3.66 \pm 1.15$ \\
\hline MS+0.2\%HA & $4.07 \pm 1.08$ & $3.83 \pm 1.02$ & $3.93 \pm 1.17$ \\
\hline MS+0.3\%HA & $3.8 \pm 1.12$ & $3.52 \pm 1.18$ & $3.63 \pm 1.08$ \\
\hline MS+0.4\%HA & $4.05 \pm 1.15$ & $3.72 \pm 0.99$ & $2.91 \pm 0.97$ \\
\hline MS+0.5\%HA & $4.04 \pm 1.0$ & $3.91 \pm 1.05$ & $2.98 \pm 1.1$ \\
\hline
\end{tabular}

In the Table 3, the mean shoot length was higher in CHA when compared to the other samples. The maximum length obtained was in MS + 0.1\% HA of $4.22 \pm 1.17$.

In the Table 4, the root length after the Rooting stage was maximum in BHA sample than the other samples. The maximum length obtained was $6.52 \pm 1.4$. The maximum root height was maximum in CHA of $8.35 \pm 0.3$.

NOTE: The table indicates only trials put with full strength MS medium as the other strengths ( $3 / 4 \mathrm{MS}, 1 / 2 \mathrm{MS}$ and $1 / 4 \mathrm{MS}$ ) medium involved showed least response with Humic acid and its commercially available products.

Table -4: Effect Of HA in Rooting Medium

\begin{tabular}{|c|c|c|c|c|c|c|}
\hline $\begin{array}{l}Z \\
0 \\
\vdots \\
0 \\
0 \\
0 \\
0 \\
0 \\
0\end{array}$ & 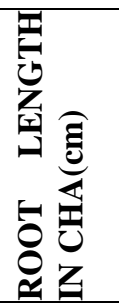 & 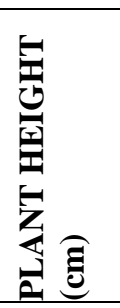 & 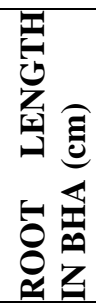 & 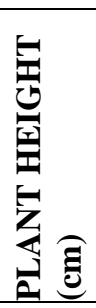 & 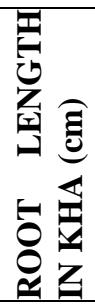 & 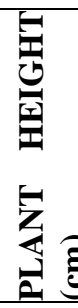 \\
\hline $\begin{array}{l}\text { MS- } \\
\text { contr } \\
\text { ol }\end{array}$ & $\begin{array}{l}5.18 \pm 1 \\
1\end{array}$ & $6.1 \pm 0.3$ & $\begin{array}{l}5.18 \\
\pm 1.1\end{array}$ & $\begin{array}{l}6.1 \pm \\
0.3\end{array}$ & $\begin{array}{l}5.18 \\
\pm 0.5\end{array}$ & $\begin{array}{l}6.1 \\
\pm 0 . \\
7\end{array}$ \\
\hline $\begin{array}{l}\mathrm{MS}+ \\
0.1 \% \\
\mathrm{HA}\end{array}$ & $\begin{array}{l}4.05 \pm 2 . \\
6\end{array}$ & $\begin{array}{l}5.99 \pm 0 . \\
5\end{array}$ & $\begin{array}{l}5.97 \\
\pm 2.6\end{array}$ & $\begin{array}{l}3.81 \\
\pm 0.5\end{array}$ & $\begin{array}{l}3.93 \\
\pm 0.8\end{array}$ & $\begin{array}{l}6.3 \\
3 \pm 0 \\
.98\end{array}$ \\
\hline $\begin{array}{l}\mathrm{MS}+ \\
0.2 \% \\
\mathrm{HA}\end{array}$ & $\begin{array}{l}4.35 \pm 3 . \\
1\end{array}$ & $\begin{array}{l}8.35 \pm 0 . \\
3\end{array}$ & $\begin{array}{l}5.75 \\
\pm 3.1\end{array}$ & $\begin{array}{l}3.96 \\
\pm 0.3\end{array}$ & $\begin{array}{l}2.91 \\
\pm 1.0 \\
1\end{array}$ & $\begin{array}{l}4.4 \\
2 \pm 1 \\
.0\end{array}$ \\
\hline $\begin{array}{l}\text { MS+ } \\
0.3 \% \\
\text { HA }\end{array}$ & $\begin{array}{l}3.96 \pm 1 \\
4\end{array}$ & $\begin{array}{l}6.33 \pm 0 . \\
1\end{array}$ & $\begin{array}{l}6.52 \\
\pm 1.4\end{array}$ & $\begin{array}{l}4.31 \\
\pm 0.1\end{array}$ & $\begin{array}{l}3.52 \\
\pm 0.9\end{array}$ & $\begin{array}{l}5.2 \\
6 \pm 1 \\
.02 \\
\end{array}$ \\
\hline $\begin{array}{l}\text { MS+ } \\
0.4 \% \\
\text { HA }\end{array}$ & $\begin{array}{l}3.81 \pm 3 \\
5\end{array}$ & $\begin{array}{l}5.44 \pm 0 \text {. } \\
1\end{array}$ & $\begin{array}{l}5.33 \\
\pm 3.5\end{array}$ & $\begin{array}{l}4.0 \pm \\
0.1\end{array}$ & $\begin{array}{l}4.29 \\
\pm 0.4\end{array}$ & $\begin{array}{l}5.4 \\
\pm 0 . \\
94 \\
\end{array}$ \\
\hline $\begin{array}{l}\text { MS+ } \\
0.5 \% \\
\text { HA }\end{array}$ & $\begin{array}{l}4.73 \pm 2 . \\
5\end{array}$ & $\begin{array}{l}6.22 \pm 0 . \\
1\end{array}$ & $\begin{array}{l}6.2 \pm \\
2.5\end{array}$ & $\begin{array}{l}4.32 \\
\pm 0.1\end{array}$ & $\begin{array}{l}3.07 \\
\pm 0.6\end{array}$ & $\begin{array}{l}3.9 \\
\pm 0 . \\
86 \\
\end{array}$ \\
\hline
\end{tabular}




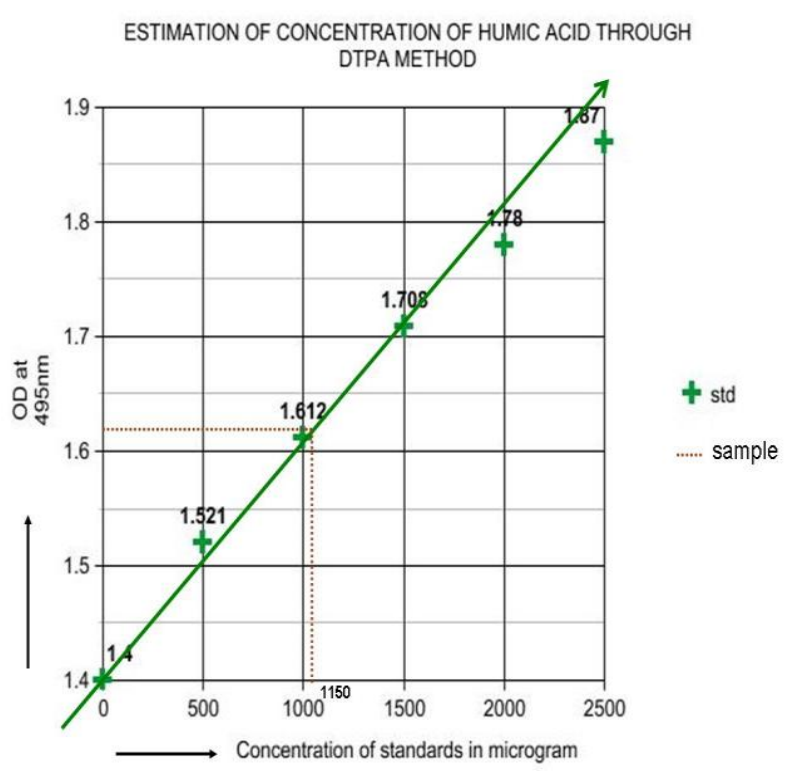

Fig 1: Estimation of Humic Acid in the Coal Sample before Comparison

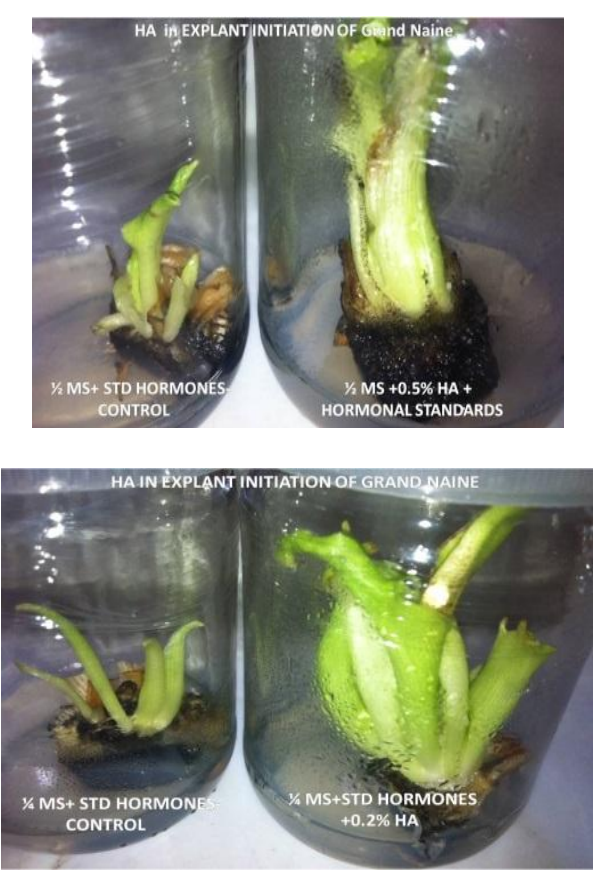

Fig 2: Explant initiation

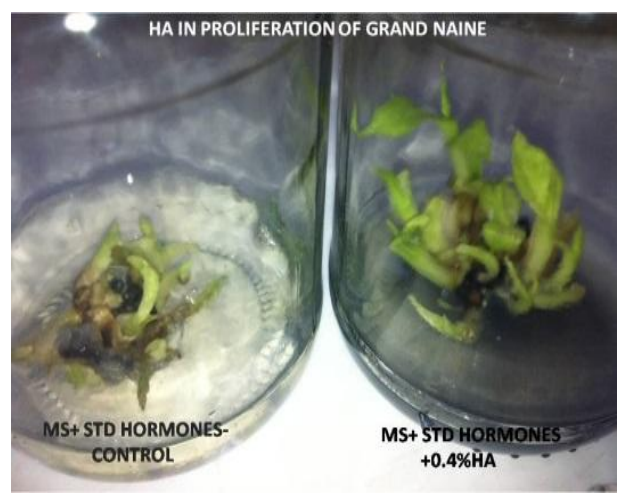

Fig 3: Proliferation stage

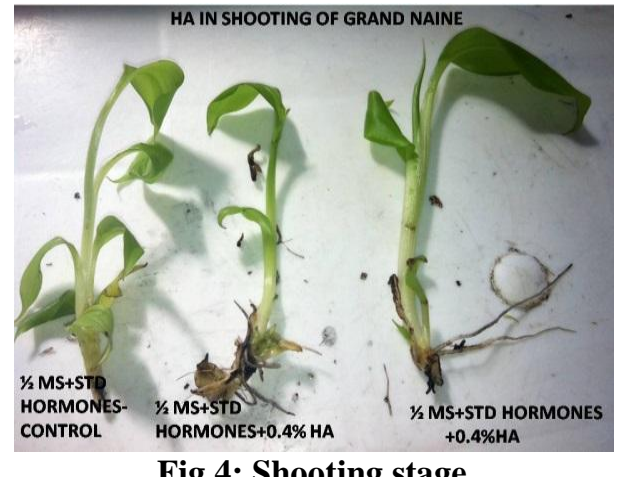

Fig 4: Shooting stage

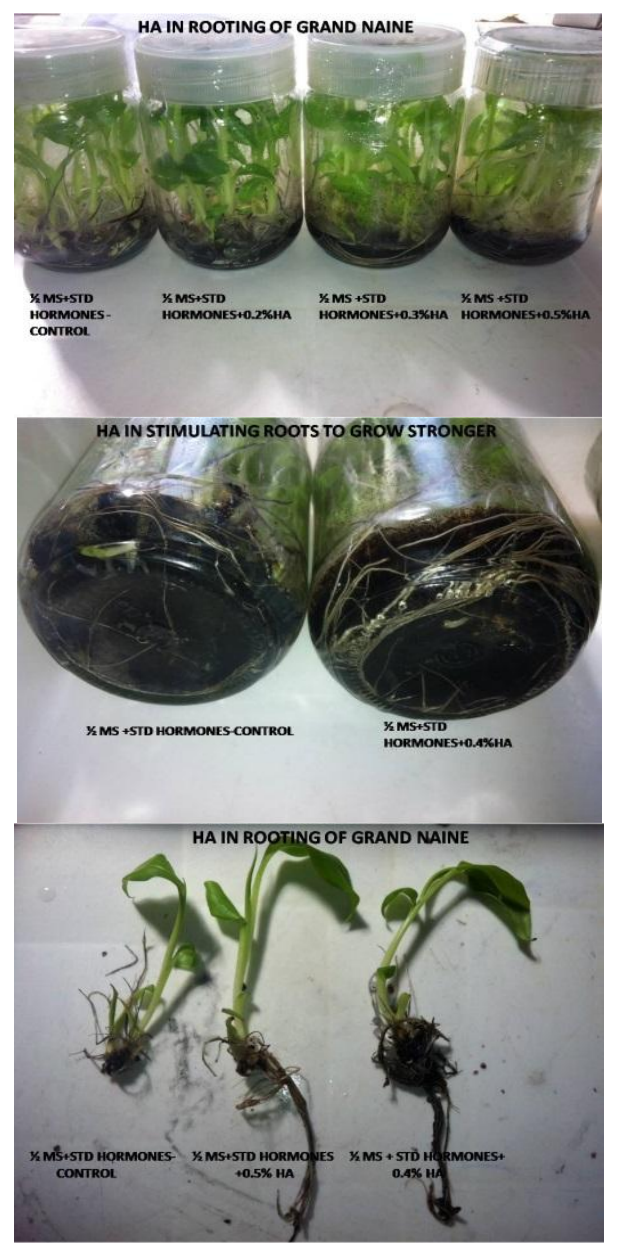

Fig 5: Rooting stage

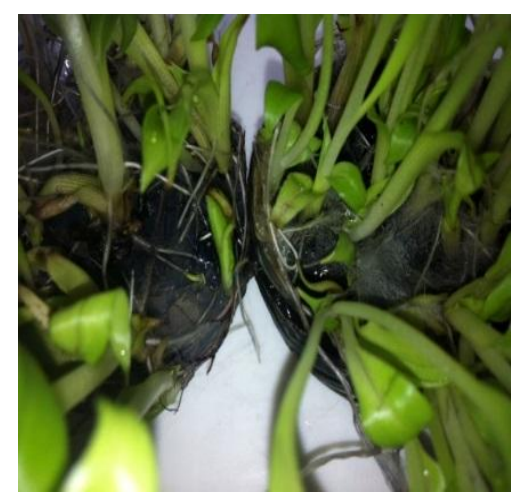

Fig 6: Fibrous roots in HA propagated plants 


\section{DISCUSSION}

The differences in bud formation, multiplication ratio, shoot height and root morphology of control, Keradix and HA exposed plants were observed, but they were not statistically significant. The growth enhancement was also evaluated by the measurement of the fresh and dry weights of the leaves in 21-day-old control plants and the leaves in plants exposed to HA. The obtained results showed statistically insignificant differences in the mass of fresh and dry weight between the leaves of control and HA exposed plants

When explants were grown on MS medium with 0.1 to $0.5 \%$ of HA, 1/2 strength MS medium with $0.5 \%$ HA and $1 / 4 \mathrm{MS}$ medium with $0.2 \%$ HA with standard hormones showed highest bud formation percentage of about $78 \%$ and $3.12 \mathrm{~g}$ of fresh weight which is cause of excellent auxin concentration suspected in full strength MS medium with HA. The control seemed to have a high level of shoot and root length than others.

Among 3 cytokinins (BAP, Kinetin and TDZ), 6 BAP in combination with NAA is used in proliferation medium. In the trial, MS with $0.4 \%$ of HA gave highest multiplication ratio of about 5.03 while the controls varied from 1.00 to 2.5 ratio.

Shooting stage is performed with different MS strength with standard Kinetin and NAA combinations. HA is found to induce roots in all the multi and shooting trials where as MS, $3 / 4 \mathrm{MS}$ and $1 / 4 \mathrm{MS}$ medium augmented with kinetin and Adenine sulphate showed comparatively less response than $1 / 2 \mathrm{MS}+0.1$ to $0.5 \% \mathrm{HA}$ in rooting of Musa accuminata. Giant roots that are highly fibrous and good root length is observed after 21 days of incubation.

\section{CONCLUSIONS}

It was concluded that the coal (Leonardite) extraction is efficient using $\mathrm{KOH}$ as solvent and the micropropagation carried out using different concentrations was found to be higher in $0.4 \% \mathrm{HA}$ which gave the higher multiplication ratio and the shoots were found to be induced in $\mathrm{MS}+0.1 \%$ HA. Giant roots were observed at the rooting stage for the BHA sample with $\mathrm{MS}+0.1-0.3 \% \mathrm{HA}$ and the plant height was observed for the CHA sample with the MS + $0.2 \%$ HA. Commercially available Keradix seemed to have a slightly lesser effect when compared with CHA and BHA.

\section{ACKNOWLEDMENTS}

The authors record their sincere thanks to the Management and Dr. M. Subbiah, Pricipal of Aringar Anna College (Arts and Science), Krishnagiri, Tamil Nadu, India for their unstinting support rendered towards us. We also extend our gratitude to Dr. V. Ravikumar, Assistant professor, Department of Biochemistry, Bharathidhasan University, Trichy and Dr.S.Gunasekaran, Dean (R\&D) and Dr. K.Valivittan, Prof. \& Head, Dept. of Biotechnology, St. Peter's University, Chennai for their valuable suggestions throughout this research work. Last but not least we thank Dr. V. Palani, Managing Director and Mrs. Manasa Satheesh, Director of Genewin Biotech, Hosur for providing necessary laboratory facilities to carry out this work in their DBT certified laboratory.

\section{REFERENCES}

[1] J.R. Brownell, G. Nordstrom, J. Marihart, G. Jorgrnsen, "Crop responses from two new leonardite extracts," Sci. Total Environ. 62, pp. 491- 499, 1987.

[2] B.V. Conger, "Cloning Agricultural Plants Via In Vitro Techniques," CRC press, Inc., Boca Raton, Florida, 273, 1980.

[3] R.J. Cooper, Chunhua Liu, D.C. Bowman, "Humic acid application affects photosynthesis, Root Development and nutrient Content of Creeping Bentgrass," Hort science. 33(6), pp. 1023-1025, 1998.

[4] S.S. Cronauer, A.D. Krikorian, "Plant regeneration via somatic embryogenesis in the seeded dioploid banana Musa ornate Roxb,” Pl. Cell Rep. 7, pp. 23-25, 1988.

[5] W.J. Davies, J. Zhang, "Root signals and the regulation of plant growth and development in drying soil.," Annual Review of Plant Physiology and Molecular Biology, 42, pp. 55-76, 1991.

[6] J.F. Dormaar, "Effects of humic substances from Chernozemic Ah horizons on nutrient uptake by Pfta seolus vulgaris an (1 Festuca scabrelLa," Can. J. Soil Sci. 55, pp. $111-118,1975$.

[7] B. Eyheraguibel, J. Silvestre, P. Morard, "Effects of humic substances derived from organic waste enhancement on the growth and mineral nutrition of maize," Bioresource Technology. 99, pp. 4206-4212, 2008.

[8] J. Ganry, "Improving banana phytosanitation and banana production excised stem tips from aseptically cultured terminal floral apex of banana," American Journal of. Ann. Bot, 53, pp. 321-328, 1986.

[9] N. Lavid, A. Schwartz, O. Yarden, Tel-ore, "The involvement of polyphenols and peroxidase acitivities in heavy metal accumulation by epidermal glands of waterlily (Nymphaeceaea)," Planta. 212, pp. 323, 2001.

[10] S.P. Mukherjee, M.A. Choudhuri, "Implications of water stress-induced changes in the levels of endogenous ascorbic acid and hydrogen peroxide in Vigna seedlings," Physiologia Plantarum. 58, pp. 166$170,1983$.

[11] T. Murashige, F. Skoog, "A revised medium for rapid growth and bioassoys with tobacoo tissue culture," Physical Pl. 15, pp. 473-97, 1962.

[12] Nardi Serenella, Diego Pizzeghello, Adele Muscolo, Angelo Vianello, "Physiological effects of humic substances on higher plants," Soil Biology \& Biochemistry. 34, pp. 1527-1536, 2002.

[13] B.S. Rauthan, M. Schnitzer, "Effects of a soil fulvic acid on the growth and nutrient Content of Cucumis Sativus Plants,” In plant and soil. 63:pp. 491, 1981.

[14] L. Resmi, A.S. Nair, "Plantlet production from the male inflorescence tips of Musa acuminata cultivars 
from South India," Plant Cell Tissue Organ Cult. 88, pp. 333-338, 2007.

[15] E. Robert Pettit, "Emeritus Associate Professor TEXAS A \& M UNIVERSITY, Organic Matter, Humus, Humates, Humic Acid, Fulvic Acid and Humin", 2007. http://www.montmorillonite.info/Humus\%20Humates $\% 20$ and \%20Humic\%20Acid.pdf

[16] T.L. Senn, R. Alta Kingman, "A review of Humus and Humic Acids," Research Series No. 145, S. C. Agricultural Experiment Station, Clemson, South Carolina, USA, 1973.

[17] A.K. Shanker, M. Djanaguiraman, R. Sudhagar, C.N. Chandrashekar, G. Pathmanabhan, "Differential antioxidative response of ascorbate glutathione pathway enzymes and metabolites to chromium speciation stress in green gram (Vigna radiata (L.) $\mathrm{R}$ Wilczek, cv CO 4) roots," Plant Sci.166, pp. 10351043, 2004.

[18] F. Stevenson, "Biochemistry of the formation of humic substances. In: Humus chemistry: genesis, compositions, reactions," John Wiley and Sons. New York, NY. Pp. 188-211, 2000.

[19] K.H. Tan, "Humic matter in soil and the environment: principles and controversies," CRC Press, 408pp, 2003.

[20] S.Y. Wang, H. Jiao, M. Faust, "Changes in ascorbate, glutathione and related enzyme activities during thiodiazuron-induced bud break of apple," Plant Physiol. 82, pp. 231-236, 1991.

\section{BIOGRAPHIES}

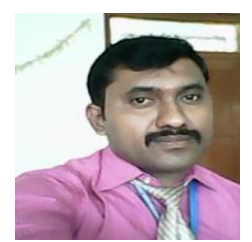

S.DHANAPAL, Date \& Place of birth: 05-01-1986, Coimbatore. Degree earned: Under Graduate in "Bachelor of science in Biochemistry" (2003-2006) at Kovai Kalaimagal college of Arts and Science, Narasipuram, Coimbatore-109, TN. Post Graduate in "Master of Science in Biotechnology" (20062008) at K.S.R College of Arts and Science, Tiruchengode, TN. Master of Philosophy in Biotechnology (2008-2009) (Periyar University II Rank), at K.S.R College of Arts and Science, Tiruchengode.TN. Pursuing Doctor of Philosophy in Biotechnology, At St Peter's University, Avadi, Chennai, as a part time programme.

Work Experience: Working as an Assistant Professor in the Department of Biotechnology at Arignar Anna College (Arts \& Science), Krishnagiri-635001.TN.From 14/06/2010 to till date.

\section{Previous publications:}

(1) J.Johnprabakaran and S.Dhanapal.2009.Analysis of Proximate Composition and Aflatoxins of Some Poultry Feeds. Asian journal of Biotechnology.1 (3).104-110.

(2) S.Dhanapal and D.Sathish sekar.2012.Effect of Humic Acid Along With Growth Regulators In Invitro Propagated Banana Plants,Current scenario in Biotechnology. Bloomsbury publishing India PVT.LTD.ISBN 978-9382563-27-3.PP:9-14.
(3) J.Johnprabakaran and S.Dhanapal.2012. Degradation of Aflatoxin B1 by Bacillus subtilis SHT 1 from Sheep Hide Tanning Site. Indian Journal of Applied Microbiology.(15)1.35-48.

(4) S.Dhanapal and D.Sathish sekar.2013.Review - Humic Acids and its Role in Plant Tissue Culture at Low Nutrient Level. Journal of Academia and Industrial Research (JAIR). ISSN: 2278-5213. 2(6). 338-340.

(5) S.Dhanapal, D.Sathish sekar, P.Manasa.2014.Enhacement of Antioxidant Potential in Musa accuminata using Humic Acid. International Journal of Agriculture Innovations \& Research (IJAIR). ISSN Online: 2319-1473. 2(4). 424-430.

(6) S.Dhanapal and D.Sathish sekar, 2014. Antioxidant Potential of Coal Extracted Humic Acid on In-vitro Propagation of Musa accuminata: A Comparison Study with Humic rooting and Keradix. International Journal of Innovative Research in Science, Engineering and Technology (IJIRSET). ISSN: 2319-8753.3(6).13649-13657. (7) S.Dhanapal, D.Sathish sekar and P.Manasa Satheesh. 2014. Efficiency of RAPD, SSR and ISSR Markers in Evaluating the Genetic Fidelity for Micropropagated Musa accuminata Plant Exposed to Coal Extracted Humic Acid And Commercially Available Products. International Journal of Agricultural Science and Research (IJASR). ISSN(P): 2250-0057; ISSN(E): 2321-0087.4(4). 77-86.

Membership: Life time member in Society for Biotechnologists in India (SBTI).The life membership no:L633.

Actively endeavor as a member in National Green Corp, Arignar Anna College (Arts \&Science),Krishnagiri. Member in JCI (Junior Chamber International), Krishnagiri.

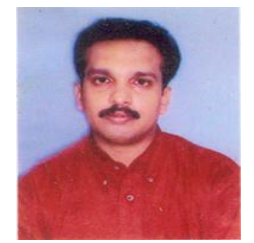

DR. D. SATHISH SEKAR, Date \& Place of birth: 09-06-1977, Krishnagiri. Degree earned: B.Sc. Biochemistry, (Allied Subject Studied - Microbiology) (March 1997) from Sengunthar Arts \& Science College, Tiruchengode, University of Madras. Post Graduate Diploma in Biotechnological Application and Pest Control Management (PGDBTA\&PCM) (March 2000) from Loyola College, Chennai M.Sc. Biochemistry (October 2000) from Vysya College, Salem, University of Madras. Ph.D. Biochemistry (November 2006) from University of Madras (A.C.Tech Guindy Campus) Chennai (Highly Commended).

Work Experience: Presently working as placement officer, NGC secretary \& Assistant Professor and Head, Department of Biotechnology, Arignar Anna College (Arts \& Science), Krishnagiri.

Dr. Sekar was awarded the title of "KALVI KAVALAR" (Philanthropist / Lions Foundation Supporter [LFS]) by Lions Clubs International - District 324 B2 (2008 - 2009). 